\title{
Cross-talk between calcium-calmodulin and nitric oxide in abscisic acid signaling in leaves of maize plants
}

\author{
Jianrong Sang ${ }^{1}$, Aying Zhang ${ }^{1}$, Fan Lin ${ }^{1}$, Mingpu Tan ${ }^{1}$, Mingyi Jiang ${ }^{1}$ \\ ${ }^{1}$ College of Life Sciences, Nanjing Agricultural University, Nanjing 210095, China
}

\begin{abstract}
Using pharmacological and biochemical approaches, the signaling pathways between hydrogen peroxide $\left(\mathrm{H}_{2} \mathrm{O}_{2}\right)$, calcium $\left(\mathrm{Ca}^{2+}\right)$-calmodulin (CaM), and nitric oxide (NO) in abscisic acid (ABA)-induced antioxidant defense were investigated in leaves of maize (Zea mays $\mathrm{L}$.) plants. Treatments with $\mathrm{ABA}, \mathrm{H}_{2} \mathrm{O}_{2}$, and $\mathrm{CaCl}_{2}$ induced increases in the generation of NO in maize mesophyll cells and the activity of nitric oxide synthase (NOS) in the cytosolic and microsomal fractions of maize leaves. However, such increases were blocked by the pretreatments with $\mathrm{Ca}^{2+}$ inhibitors and CaM antagonists. Meanwhile, pretreatments with two NOS inhibitors also suppressed the $\mathrm{Ca}^{2+}$-induced increase in the production of NO. On the other hand, treatments with ABA and the NO donor sodium nitroprusside (SNP) also led to increases in the concentration of cytosolic $\mathrm{Ca}^{2+}$ in protoplasts of mesophyll cells and in the expression of calmodulin 1 ( CaMI) gene and the contents of $\mathrm{CaM}$ in leaves of maize plants, and the increases induced by ABA were reduced by the pretreatments with a NO scavenger and a NOS inhibitor. Moreover, SNP-induced increases in the expression of the antioxidant genes superoxide dismutase 4 (SOD4), cytosolic ascorbate peroxidase ( $A A P X)$, and glutathione reductase 1 (GR1) and the activities of the chloroplastic and cytosolic antioxidant enzymes were arrested by the pretreatments with $\mathrm{Ca}^{2+}$ inhibitors and $\mathrm{CaM}$ antagonists. Our results suggest that $\mathrm{Ca}^{2+}-\mathrm{CaM}$ functions both upstream and downstream of NO production, which is mainly from NOS, in $\mathrm{ABA}$ - and $\mathrm{H}_{2} \mathrm{O}_{2}$-induced antioxidant defense in leaves of maize plants.
\end{abstract} Keywords: abscisic acid, antioxidant defense, calmodulin, cytosolic calcium, nitric oxide, nitric oxide synthase, Zea mays Cell Research (2008) 18:577-588. doi: 10.1038/cr.2008.39; published online 25 March 2008

\section{Introduction}

Abscisic acid (ABA), as a stress signal, plays critical roles in the regulation of plant water balance and osmotic stress tolerance under drought, cold, and salt stress conditions $[1,2]$. Accumulating evidence indicates that ABAenhanced water stress tolerance is, at least in part, due to the induction of antioxidant defense systems [3-6]. Previous studies have shown that NADPH oxidase, hydrogen peroxide $\left(\mathrm{H}_{2} \mathrm{O}_{2}\right)$, nitric oxide $(\mathrm{NO})$, calcium $\left(\mathrm{Ca}^{2+}\right)$-calmodulin $(\mathrm{CaM})$, and mitogen-activated protein kinase (MAPK) are required for $\mathrm{ABA}$-induced up-regulation in the activities of antioxidant enzymes such as superoxide dismutase (SOD), catalase (CAT), and ascorbate peroxidase (APX) and glutathione reductase (GR) in leaves of maize plants [7-11]. It has been shown that $\mathrm{ABA}$-induced $\mathrm{H}_{2} \mathrm{O}_{2}$ production

Correspondence: Mingyi Jiang

Tel: +86-25-84396372; Fax: +86-25-84396542

E-mail: myjiang@njau.edu.cn

Received 6 August 2007; revised 29 September 2007; accepted 1 November 2007; published online 25 March 2008 mediates NO generation, which, in turn, activates MAPK and results in the up-regulation in the expression and the activities of antioxidant enzymes in ABA signaling [11]. $\mathrm{Ca}^{2+}$-CaM has also been shown to be necessary for ABAinduced antioxidant defense and function both upstream and downstream of $\mathrm{H}_{2} \mathrm{O}_{2}$ production in leaves of maize plants [9]. However, whether $\mathrm{Ca}^{2+}-\mathrm{CaM}$ is involved in NO-induced antioxidant defense in plants and, if so, what the relationship between $\mathrm{Ca}^{2+}-\mathrm{CaM}$ and NO in the ABA signaling is remains to be determined.

An increasing body of evidence indicates that NO, which was first identified as a unique diffusible molecular messenger in animals, plays important roles in various physiological processes in plants, including defense responses and programmed cell death (PCD), hormone responses, abiotic stress, root and xylem development, germination, iron homeostasis, and flowering [12-18]. In mammals, NO is formed exclusively by the enzyme nitric oxide synthase (NOS). NOS catalyzes the conversion of L-arginine into Lcitrulline and $\mathrm{NO}$ in the presence of molecular oxygen [12, 14, 17, 18]. Three isoforms of NOS have been identified in mammalian species: neuronal NOS (nNOS), endothelial 
NOS (eNOS), and inducible (iNOS) $[12,15,18]$. nNOS and eNOS are classified as constitutive NOSs because they are rapidly activated by $\mathrm{Ca}^{2+}$ and show limited transcriptional regulation. By contrast, iNOS constitutively binds $\mathrm{Ca}^{2+}$ and $\mathrm{CaM}$ and is regulated primarily at the transcriptional level. In plants, there are several potential sources of NO, including NOS-like enzyme, nitrate reductase (NR), and non-enzymatic sources $[12,14,15,17]$. Although no plant NOS similar to the mammalian one has been identified [19-21], several lines of evidence have demonstrated the presence of NOS-like activity in plant cells $[12,14,17,18$,
22-24]. The NOS activity in pea leaf peroxisomes has been biochemically characterized, which is strictly dependent on L-arginine, NADPH, tetrahydrobiopterin $\left(\mathrm{BH}_{4}\right)$, and $\mathrm{CaM}$, and requires $\mathrm{Ca}^{2+}[22]$. Previous studies showed that pretreatment with $N^{\mathrm{G}}$-nitro-L-Arg methyl ester (L-NAME), a well-known competitive inhibitor of mammalian NOS, reduced $\mathrm{ABA}$-induced increases in the production of $\mathrm{NO}$ in pea guard cells [25] and maize mesophyll cells [11], suggesting that NOS is involved in ABA signaling. However, more evidence is required for the involvement of NOS in ABA-induced antioxidant defense in plants.
A

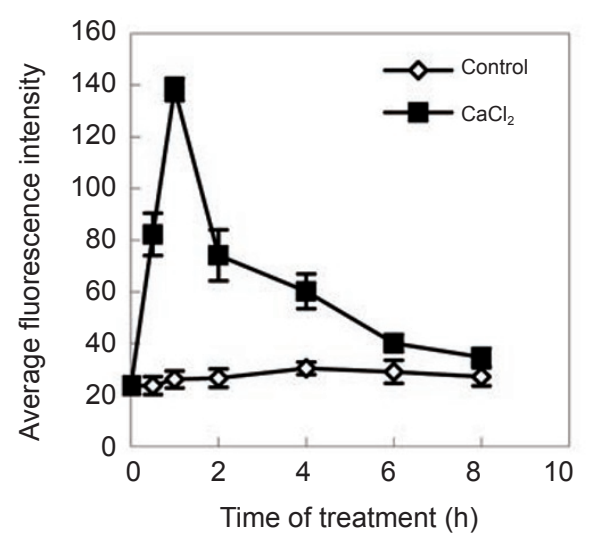

B
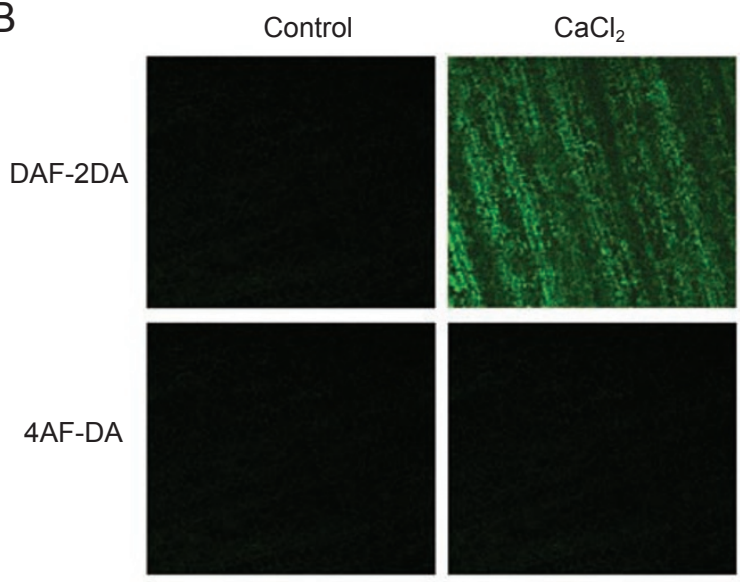

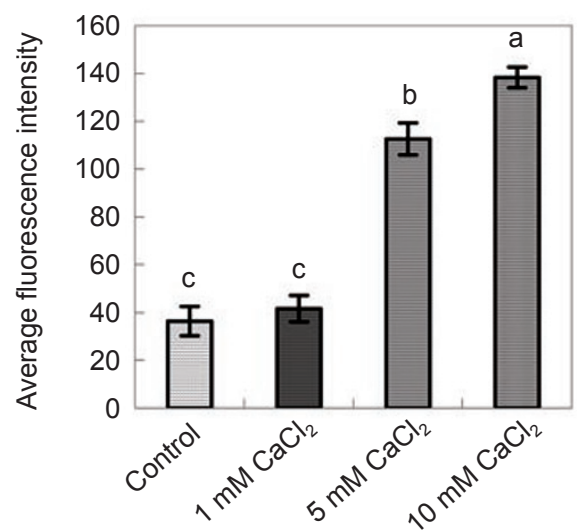

C

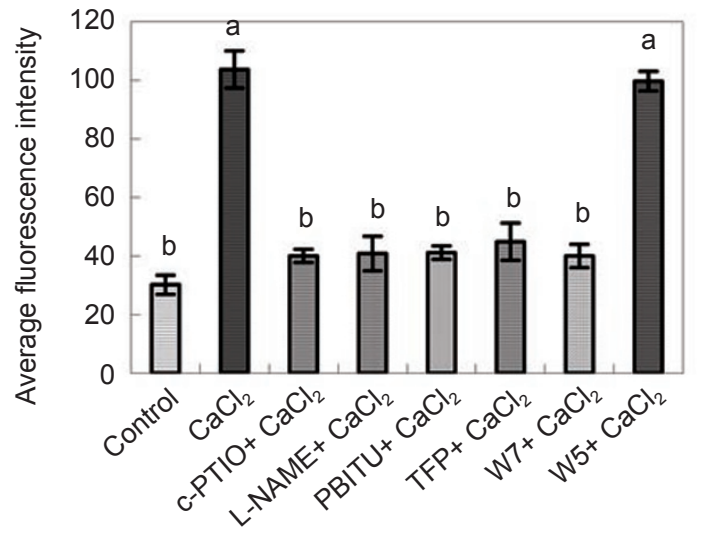

Figure 1 Nitric oxide production in response to $\mathrm{CaCl}_{2}$ treatment in maize leaves. (A) Time course and dose dependence for $\mathrm{CaCl}_{2}$-induced NO production in mesophyll cells of maize leaves. The detached plants were treated with $10 \mathrm{mM} \mathrm{CaCl}_{2}$ for various times (left), or different concentrations of $\mathrm{CaCl}_{2}(1,5$ and $10 \mathrm{mM})$ for $1 \mathrm{~h}$ (right), and then the leaf segments were loaded with DAF-2DA and detected by CLSM. (B) DAF-2DA fluorescence accumulation in $\mathrm{CaCl}_{2}$-treated mesophyll cells of maize leaves. The detached plants were treated with distilled water (control), $10 \mathrm{mM} \mathrm{CaCl}_{2}$ for $1 \mathrm{~h}$, and the leaf segments were loaded with DAF-2DA (top) or 4AF-DA (bottom) and detected by CLSM. (C) Effects of pretreatments with NO scavenger, NOS inhibitors and $\mathrm{CaM}$ antagonists on $\mathrm{CaCl}_{2}$-induced $\mathrm{NO}$ production. The detached plants were pretreated with distilled water, $200 \mu \mathrm{M} \mathrm{c}-\mathrm{PTIO}$, $200 \mu \mathrm{M}$ L-NAME, $5 \mathrm{mM}$ PBITU, $300 \mu \mathrm{M}$ TFP, $200 \mu \mathrm{M} \mathrm{W7}$, and $200 \mu \mathrm{M} \mathrm{W} 5$ for $2 \mathrm{~h}$, and then exposed to $10 \mathrm{mM} \mathrm{CaCl}_{2}$ treatment for $1 \mathrm{~h}$. Detached plants treated with distilled water served as control. In (A and $\mathbf{C}$ ), values are the means \pm SE of three different experiments. Means denoted by the same letter did not significantly differ at $P<0.05$ according to Duncan's multiple range test. In (B), experiments were repeated at least three times with similar results. 
In the present study, using pharmacological and biochemical approaches, the signaling pathways between $\mathrm{H}_{2} \mathrm{O}_{2}, \mathrm{Ca}^{2+} / \mathrm{CaM}$, and $\mathrm{NO}$ in ABA-induced up-regulation in the expression of several antioxidant genes such as superoxide dismutase 4 (SOD4), encoding a cytosolic isoform of SOD, cytosolic ascorbate peroxidase ( $c A P X)$, encoding a cytosolic isoform of APX, and glutathione reductase 1 (GR1), encoding a plastidial isoform of GR, and of the total activities of the chloroplastic and cytosolic antioxidant enzymes SOD, APX, and GR in leaves of maize plants were investigated. Our results showed that $\mathrm{Ca}^{2+}-\mathrm{CaM}$ is required for ABA- and $\mathrm{H}_{2} \mathrm{O}_{2}$-induced increase in the production of $\mathrm{NO}$ and the activity of NOS in leaves of maize plants, and the increases in the production of NO are mainly from NOS. Our data also suggest that there exists cross-talk between $\mathrm{Ca}^{2+}-\mathrm{CaM}$ and $\mathrm{NO}$ in $\mathrm{ABA}$ and $\mathrm{H}_{2} \mathrm{O}_{2}$ signaling.

\section{Results}

Involvement of CaM in exogenous $\mathrm{Ca}^{2+}$-induced NO generation and NOS activity

To investigate the effect of $\mathrm{CaCl}_{2}$ treatment on the production of NO in leaves of maize plants, the leaf segments from treated and untreated leaves were loaded with the NO-specific fluorescent dye 4,5-diaminofluorescein diacetate (DAF-2DA), and confocal laser scanning microscopy (CLSM) was used to monitor changes in NOinduced fluorescence in mesophyll cells of maize leaves. Treatment with $10 \mathrm{mM} \mathrm{CaCl}_{2}$ led to a rapid increase in DAF-2DA fluorescence intensity (Figure 1A). The DAF2DA fluorescence was visible as early as $0.5 \mathrm{~h}$, maximized at $1 \mathrm{~h}$, and then decreased after $2 \mathrm{~h}$ of $\mathrm{CaCl}_{2}$ treatment. The $\mathrm{CaCl}_{2}$-induced fluorescence intensity was dose-dependent in the concentration range of 1-10 $\mathrm{mM} \mathrm{CaCl}_{2}$ (Figure 1A). By contrast, no increase in fluorescence intensity was observed in $\mathrm{CaCl}_{2}$-treated leaves when the leaf segments were loaded with the negative probe 4-amino fluorescein diacetate (4AF-DA), which lacks one of the amino groups that constitutes the NO specificity domain of the DAF2DA molecule (Figure 1B). Pretreatments with the NO scavenger c-PTIO and the NOS inhibitors L-NAME and PBITU substantially reduced the DAF-2DA fluorescence intensity induced by $\mathrm{CaCl}_{2}$ treatment (Figure 1C). These results clearly indicate that $\mathrm{Ca}^{2+}$ can induce an increased generation of NO in mesophyll cells of maize leaves.

The fact that NOS inhibitors inhibit the generation of $\mathrm{NO}$ induced by $\mathrm{CaCl}_{2}$ treatment (Figure $1 \mathrm{C}$ ) suggests that NO production is associated with the activity of NOS in leaves of maize plants. To further determine the relationship between NO generation and NOS activity, the cytosolic and microsomal fractions of maize leaves were isolated and the activity of NOS was determined. Under the control conditions, the activity of NOS in the microsomal fraction was higher than that in the cytosolic fraction (Figure 2A). Treatment with $10 \mathrm{mM} \mathrm{CaCl}_{2}$ resulted in a rapid increase in the activity of NOS in the cytosolic and microsomal fractions of maize leaves. After $1 \mathrm{~h}$ of $\mathrm{CaCl}_{2}$ treatment, the activity of NOS in the cytosolic and microsomal fractions reached the maximum values, and increased by $92.7 \%$ and $148 \%$, respectively, compared with the control values. Pretreatments with the NOS inhibitors L-NAME and PBITU completely blocked the increase in the activity of NOS in the cytosolic and microsomal fractions induced by $\mathrm{CaCl}_{2}$ treatment (Figure 2B), but these pretreatments alone did not affect the activity of NOS in the control leaves (data not shown).

In order to investigate whether $\mathrm{Ca}^{2+}$-induced increases in the generation of NO and the activity of NOS are related to the action of $\mathrm{CaM}$, the $\mathrm{CaM}$ antagonists trifluoperazine (TFP) and N-(6-aminohexyl)-5-chloro-1-naphthalene sulfonamide hydrochloride (W7) were used. Pretreatments with these antagonists substantially prevented the increases in the generation of NO (Figure 1C) and the activity of NOS in the cytosolic and microsomal fractions (Figure 2B) induced by $\mathrm{CaCl}_{2}$ treatment. However, pretreatment with $\mathrm{W} 5$, an inactive structural analog of W7, had very little effect on $\mathrm{CaCl}_{2}$-induced increases in the production of $\mathrm{NO}$ and the activity of NOS in leaves of maize plants exposed to $\mathrm{CaCl}_{2}$ treatment. These results suggest that $\mathrm{CaM}$ is necessary for the generation of NO and the activity of NOS induced by exogenous $\mathrm{Ca}^{2+}$ in leaves of maize plants.

$\mathrm{Ca}^{2+}$-CaM is required for $\mathrm{ABA}$ - and $\mathrm{H}_{2} \mathrm{O}_{2}$-induced $\mathrm{NO}$ generation and NOS activity

Previous studies showed that both ABA and $\mathrm{H}_{2} \mathrm{O}_{2}$ induce NO generation in maize mesophyll cells [11], and also induce increases in the concentration of cytosolic $\mathrm{Ca}^{2+}\left(\left[\mathrm{Ca}^{2+}\right]_{\mathrm{i}}\right)$ in the protoplasts of mesophyll cells and in the expression of CaM1 gene and the content of $\mathrm{CaM}$ in leaves of maize plants [9]. To investigate whether $\mathrm{Ca}^{2+}$ $\mathrm{CaM}$ is involved in ABA- and $\mathrm{H}_{2} \mathrm{O}_{2}$-induced generation of $\mathrm{NO}$, the $\mathrm{Ca}^{2+}$ chelator ethylene glycol-bis(2-aminoethyl ether)-N,N,N',N'-tetraacetic acid (EGTA), the $\mathrm{Ca}^{2+}$ channel blockers $\mathrm{LaCl}_{3}$ and verapamil, and the CaM antagonists TFP and W7 were used. Pretreatments with these inhibitors significantly reduced the increase in the production of $\mathrm{NO}$ induced by $\mathrm{ABA}$ or $\mathrm{H}_{2} \mathrm{O}_{2}$ in mesophyll cells of maize leaves (Figure $3 \mathrm{~A}$ ), but these pretreatments alone did not affect the production of $\mathrm{NO}$ in the untreated leaves (data not shown). Moreover, pretreatment with W5 had little effect on the ABA- and $\mathrm{H}_{2} \mathrm{O}_{2}$-induced $\mathrm{NO}$ production in mesophyll cells of maize leaves (Figure 3A). These results suggest that $\mathrm{Ca}^{2+}-\mathrm{CaM}$ is required for $\mathrm{ABA}-$ and $\mathrm{H}_{2} \mathrm{O}_{2}$-induced NO production in leaves of maize plants. 

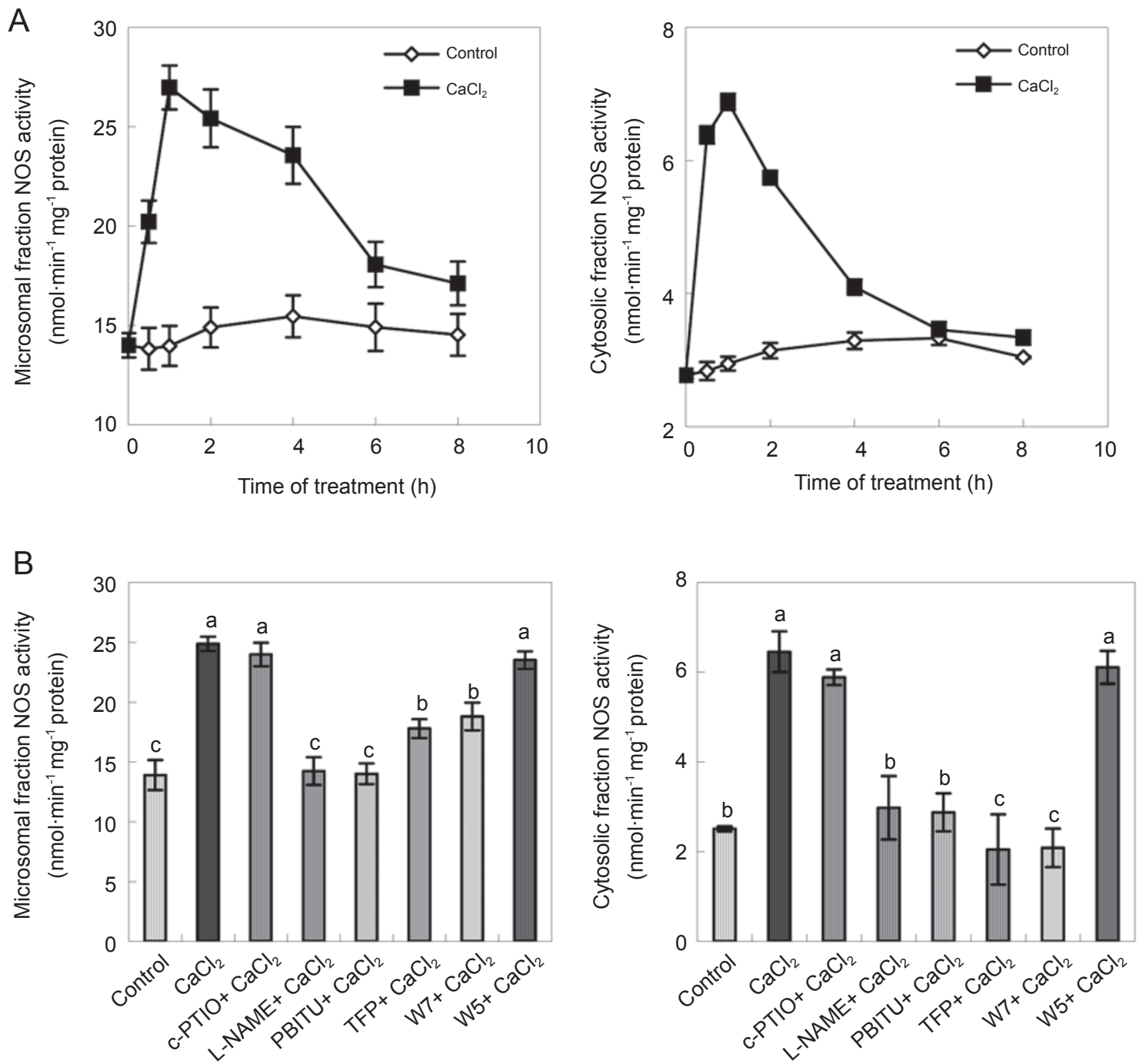

Figure $2 \mathrm{CaCl}_{2}$-induced changes in the activity of NOS in cytosolic and microsomal fractions of maize leaves (A) and the effects of pretreatments with NO scavenger, NOS inhibitors, and CaM antagonists on the activity of NOS (B) in leaves of maize plants exposed to $\mathrm{CaCl}_{2}$ treatment. (A) The detached plants were treated with distilled water (control) and $10 \mathrm{mM} \mathrm{CaCl}$ for various times. (B) The detached plants were pretreated with distilled water, $200 \mu \mathrm{M}$ c-PTIO, $200 \mu \mathrm{M} \mathrm{L-NAME}, 5 \mathrm{mM}$ PBITU, $300 \mu \mathrm{M}$ TFP, $200 \mu \mathrm{M} \mathrm{W7}$, and $200 \mu \mathrm{M}$ W5 for $2 \mathrm{~h}$, and then exposed to $10 \mathrm{mM} \mathrm{CaCl}_{2}$ or distilled water treatment for $1 \mathrm{~h}$. Values are means \pm SE of three different experiments. Means denoted by the same letter did not significantly differ at $P<0.05$ according to Duncan's multiple range test.

Treatments with ABA and $\mathrm{H}_{2} \mathrm{O}_{2}$ also led to an increase in the activity of NOS in the cytosolic and microsomal fractions of maize leaves (Figure 3B), and such an increase was blocked by the pretreatments with EGTA, $\mathrm{LaCl}_{3}$ and verapamil, and TFP and W7. However, pretreatment with W5 had little effect on the increase in the activity of NOS induced by $\mathrm{ABA}$ or $\mathrm{H}_{2} \mathrm{O}_{2}$ treatment. These results suggest that the ABA- and $\mathrm{H}_{2} \mathrm{O}_{2}$-induced NOS activity is related to $\mathrm{Ca}^{2+}-\mathrm{CaM}$.

NO induces increases in $\left[\mathrm{Ca}^{2+}\right]_{i}$ and CaM
To investigate whether $\mathrm{NO}$ also affects the levels of $\mathrm{Ca}^{2+}-\mathrm{CaM}$, the NO donor SNP was used. Treatment with $\mathrm{SNP}$ led to a rapid increase in $\mathrm{Ca}^{2+}$-sensitive fluorescence of the protoplasts, which were isolated from untreated maize leaves and loaded with the Fluo-3/AM, a $\mathrm{Ca}^{2+}$-sensitive fluorescent probe [31], and observed by CLSM (Figure 4A). The fluorescence intensity of the protoplasts reached a maximum value at $6 \mathrm{~min}$, which was 1.9-fold higher than that in the control, and then remained high during the 30 min of SNP treatment. By contrast, treatment with sodium ferricyanide $[\mathrm{Fe}(\mathrm{III}) \mathrm{CN}]$, which shares many structural 
A
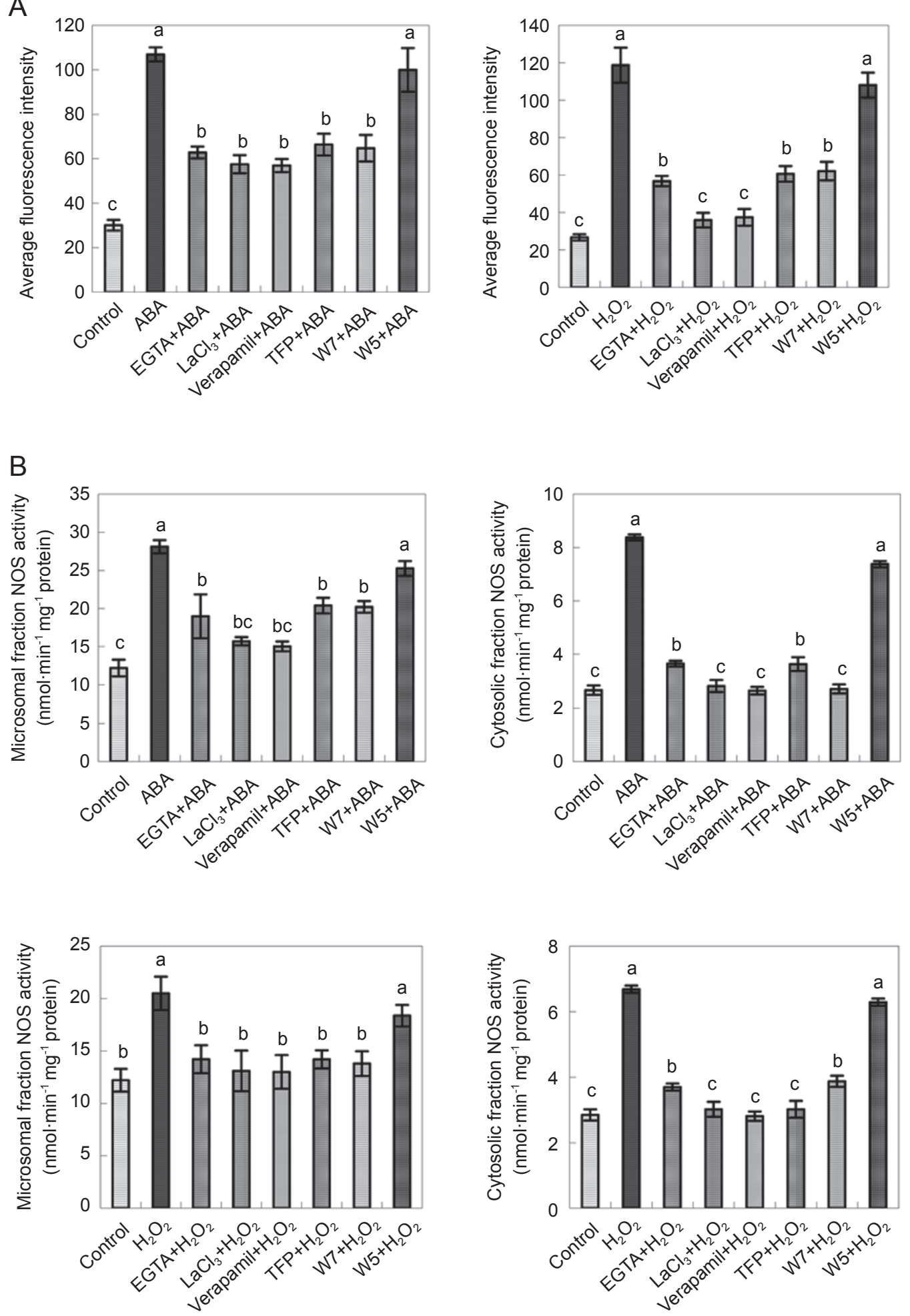

Figure 3 Effects of pretreatments with $\mathrm{Ca}^{2+}$ inhibitors and CaM antagonists on $\mathrm{ABA}$ - or $\mathrm{H}_{2} \mathrm{O}_{2}$-induced $\mathrm{NO}$ production in mesophyll cells of maize leaves (A) and NOS activity in cytosolic and microsomal fractions of maize leaves (B). The detached plants were pretreated with distilled water, $10 \mathrm{mM}$ EGTA, $5 \mathrm{mM} \mathrm{LaCl}_{3}, 100 \mu \mathrm{M}$ verapamil, $300 \mu \mathrm{M}$ TFP, $200 \mu \mathrm{M}$ W7 and $200 \mu \mathrm{M}$ W5 for $2 \mathrm{~h}$, and then exposed to $100 \mu \mathrm{M} \mathrm{ABA}$ or $10 \mathrm{mM} \mathrm{H}_{2} \mathrm{O}_{2}$ or distilled water treatment for $2 \mathrm{~h}$. Values are means $\pm \mathrm{SE}$ of three different experiments. Means denoted by the same letter did not significantly differ at $P<0.05$ according to Duncan's multiple range test. 

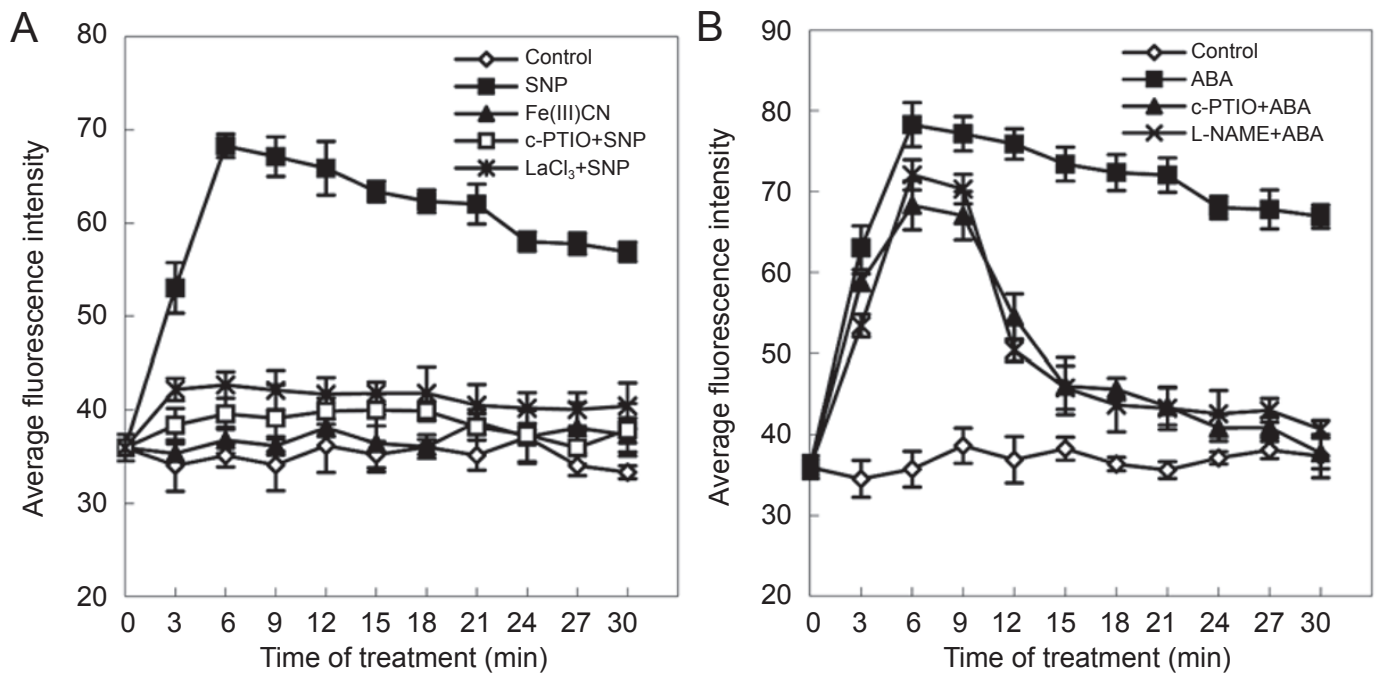

Figure 4 Changes of cytosolic calcium concentration $\left(\left[\mathrm{Ca}^{2+}\right]_{i}\right)$ in maize mesophyll protoplasts exposed to SNP (A) or ABA (B) treatment. The protoplasts loaded with Fluo-3/AM were pretreated with distilled water, $20 \mu \mathrm{M} \mathrm{c-PTIO,} 20 \mu \mathrm{M}$ L-NAME and 500 $\mu \mathrm{M} \mathrm{LaCl}{ }_{3}$ for $3 \mathrm{~min}$, respectively, and then exposed to $10 \mu \mathrm{M}$ SNP or $10 \mu \mathrm{M} \mathrm{Fe}(\mathrm{III}) \mathrm{CN}$ or $10 \mu \mathrm{M} \mathrm{ABA}$ or distilled water for various times, and detected by CLSM. The fluorescence intensity was measured by fluorescence microscopy and calculated as the average value of those obtained by scanning over 60 protoplasts from different experiments. All experiments were repeated at least five times with similar results.

features with SNP but lacks a nitroso group and thus the ability to generate NO [36], did not induce the increase in the $\mathrm{Ca}^{2+}$-sensitive fluorescence of the protoplasts. Moreover, pretreatments with c-PTIO and $\mathrm{LaCl}_{3}$ substantially reduced the increase in fluorescence intensity induced by SNP treatment (Figure 4A). These results clearly indicate that $\mathrm{NO}$ itself can induce the increase in the concentration of $\left[\mathrm{Ca}^{2+}\right]_{\mathrm{i}}$. Meanwhile, SNP treatment also caused clear increases in the transcript level of CaM1, which encodes a maize CaM isoform [9, 37], analyzed by semi-quantitative RT-PCR, and in the content of CaM in leaves of maize plants (Figure 5A and 5B).

To investigate whether ABA-induced increases in the levels of $\mathrm{Ca}^{2+}-\mathrm{CaM}$ are related to $\mathrm{ABA}$-induced $\mathrm{NO}$ generation, the detached plants were pretreated with the NO scavenger c-PTIO and the NOS inhibitor L-NAME, and then exposed to ABA treatment. Experimental results showed that pretreatments with c-PTIO and L-NAME had very little effect on the ABA-induced increase in the concentration of $\left[\mathrm{Ca}^{2+}\right]_{\mathrm{i}}$ within the first 9 min of ABA treatment (Figure 4B) and in the expression of CaM1 within the first $1 \mathrm{~h}$ of ABA treatment (Figure 5A) and in the content of CaM within the first $1.5 \mathrm{~h}$ of ABA treatment (Figure 5B), but substantially blocked the increases in the concentration of $\left[\mathrm{Ca}^{2+}\right]_{\mathrm{i}}$ after 12 min of ABA treatment and in the expression of $C a M 1$ after $1.5 \mathrm{~h}$ of ABA treatment and in the content of $\mathrm{CaM}$ after $2 \mathrm{~h}$ of ABA treatment, suggesting that the initial increase in $\mathrm{Ca}^{2+}-\mathrm{CaM}$ induced by $\mathrm{ABA}$ is not dependent on $\mathrm{ABA}$-induced $\mathrm{NO}$ production in leaves of maize plants exposed to ABA treatment.

$\mathrm{Ca}^{2+}-\mathrm{CaM}$ is involved in NO-induced antioxidant defense

It has been shown that $\mathrm{NO}$ can induce increases in the expression of antioxidant genes such as CAT1, cAPX, $S O D 4$, and $G R 1$ and the total activities of these antioxidant enzymes [11]. In order to investigate whether NO-induced antioxidant defense is related to the increases in $\mathrm{Ca}^{2+}-\mathrm{CaM}$, the detached plants were pretreated with the $\mathrm{Ca}^{2+}$ chelator EGTA, the $\mathrm{Ca}^{2+}$ channel blocker $\mathrm{LaCl}_{3}$, and the CaM antagonists TFP and W7, respectively, and then exposed to SNP treatment. Pretreatments with these $\mathrm{Ca}^{2+}$ inhibitors and CaM antagonists almost fully prevented the SNP-induced increases in the expression of the antioxidant genes SOD4, $C A P X$, and GR1 (Figure 6A) and the activities of chloroplastic and cytosolic SOD, APX, and GR (Figure $6 \mathrm{~B})$, but pretreatment with W5 had very little effect on SNPinduced increases in the expression and activities of these antioxidant enzymes in leaves of maize plants. Meanwhile, treatment with $\mathrm{Fe}(\mathrm{III}) \mathrm{CN}$ did not induce the increases in the expression and activities of these antioxidant enzymes. These results clearly suggest that $\mathrm{Ca}^{2+}-\mathrm{CaM}$ is required for the NO-induced antioxidant defense.

\section{Discussion}

Previous studies showed that ABA-induced NO production is dependent on $\mathrm{H}_{2} \mathrm{O}_{2}$ generation in Arabidopsis guard cells [38] and in maize mesophyll cells [11]. However, 

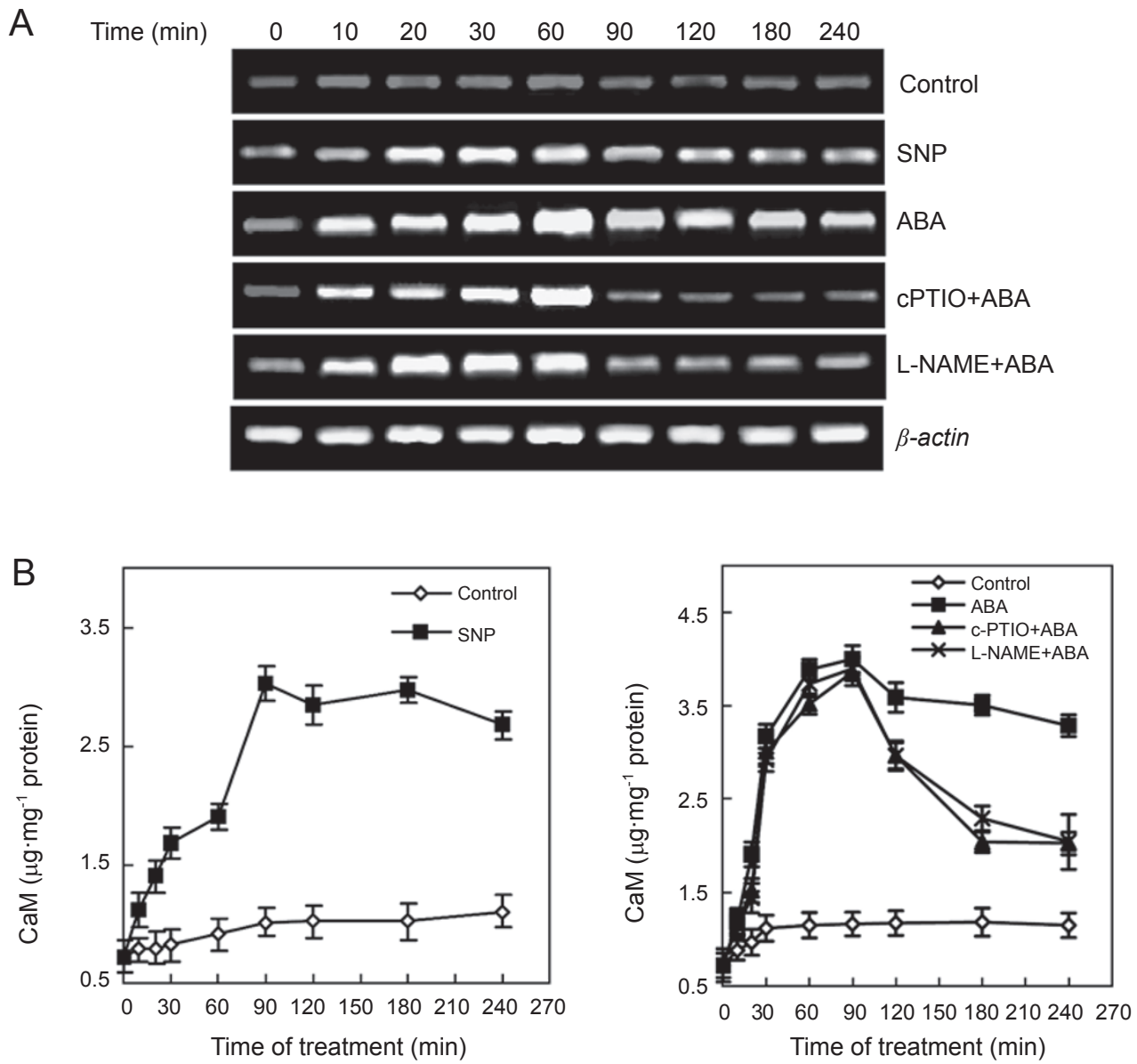

Figure 5 SNP- and ABA-induced changes in the expression of the calmodulin 1 (CaM1) gene and the content of CaM in leaves of maize plants. (A) Transcript levels of CaM1 analyzed by RT-PCR. (B) Time-course of changes in the content of CaM. The detached plants were pretreated with distilled water, $200 \mu \mathrm{M}$ c-PTIO, and $200 \mu \mathrm{M} \mathrm{L-NAME}$ for $2 \mathrm{~h}$, and then exposed to $100 \mu \mathrm{M}$ SNP or $100 \mu \mathrm{M}$ ABA for various times. Detached plants treated with distilled water served as controls. In (A), experiments were repeated at least three times with similar results. In (B), the values are the mean \pm SE of three different experiments. Means denoted by the same letter did not significantly differ at $P<0.05$ according to Duncan's multiple range test.

how $\mathrm{H}_{2} \mathrm{O}_{2}$ regulates $\mathrm{NO}$ production in $\mathrm{ABA}$ signaling is not clear. It has been shown that ABA-induced $\mathrm{H}_{2} \mathrm{O}_{2}$ can induce increases in the concentration of $\left[\mathrm{Ca}^{2+}\right]_{\mathrm{i}}$ and the expression of CaM1 and the content of $\mathrm{CaM}$ in leaves of maize plants [9], and that $\mathrm{Ca}^{2+}$ is required for $\mathrm{H}_{2} \mathrm{O}_{2}$-induced $\mathrm{NO}$ production in guard cells of mung bean [39]. The $\mathrm{Ca}^{2+}$ dependent NO production was also observed in tobacco cells challenged by the elicitor cryptogein [40] and in the endopolygalacturonase 1 (BcPG1)-elicited grapevine cells [41]. Here we provide evidence that both $\mathrm{Ca}^{2+}$ and $\mathrm{CaM}$ are involved in ABA- and $\mathrm{H}_{2} \mathrm{O}_{2}$-induced $\mathrm{NO}$ production in leaves of maize plants. Our data showed that ABA- and $\mathrm{H}_{2} \mathrm{O}_{2}$-induced increase in the generation of $\mathrm{NO}$ was substantially blocked by pretreatments with the $\mathrm{Ca}^{2+}$ chelator EGTA, the $\mathrm{Ca}^{2+}$ channel blockers $\mathrm{LaCl}_{3}$ and verapamil, and the CaM antagonists TFP and W7 (Figure 3A). However, pretreatment with W5, an inactive structural analog of W7, had very little effect on the ABA- and $\mathrm{H}_{2} \mathrm{O}_{2}$-induced $\mathrm{NO}$ production in mesophyll cells of maize leaves. Moreover, exogenous $\mathrm{Ca}^{2+}$ also induced an increase in the production of NO (Figure 1A), and the increase was prevented by pretreatments with the CaM antagonists TFP and W7 (Figure 1C). Similarly, pretreatment with W5 did not affect the exogenous $\mathrm{Ca}^{2+}$-induced $\mathrm{NO}$ production. Although the absolute specificities of these inhibitors used in this study can always be questioned, it has been shown that these inhibitors in the concentration range used in the present study should make it feasible to study the role of $\mathrm{Ca}^{2+}$ and $\mathrm{CaM}$ in plant cells $[7,9,42,43]$. Our results clearly suggest that $\mathrm{Ca}^{2+} / \mathrm{CaM}$ is required for the $\mathrm{ABA}-$ and $\mathrm{H}_{2} \mathrm{O}_{2}$-induced NO production in maize mesophyll cells.

In animals, NO production is catalyzed primarily by 
A

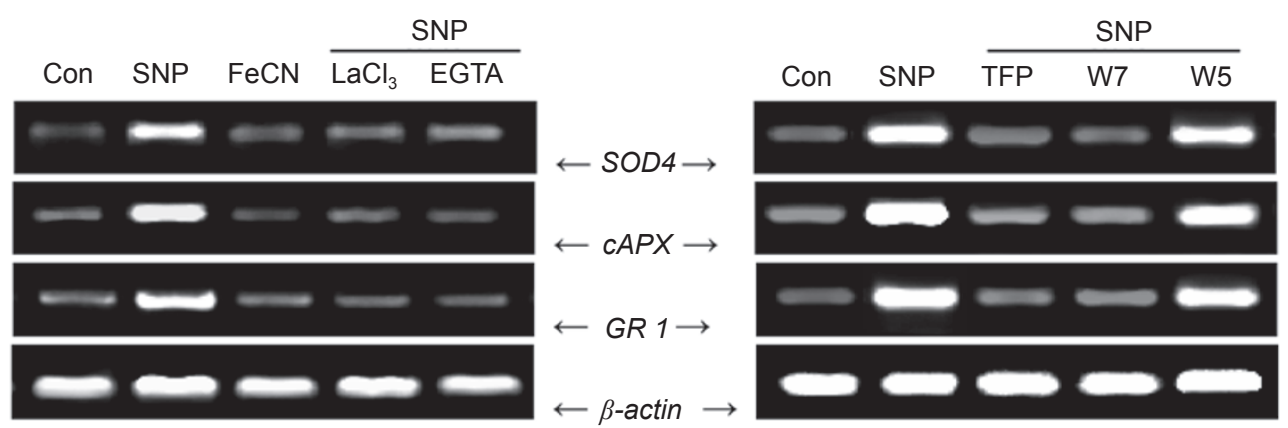

B
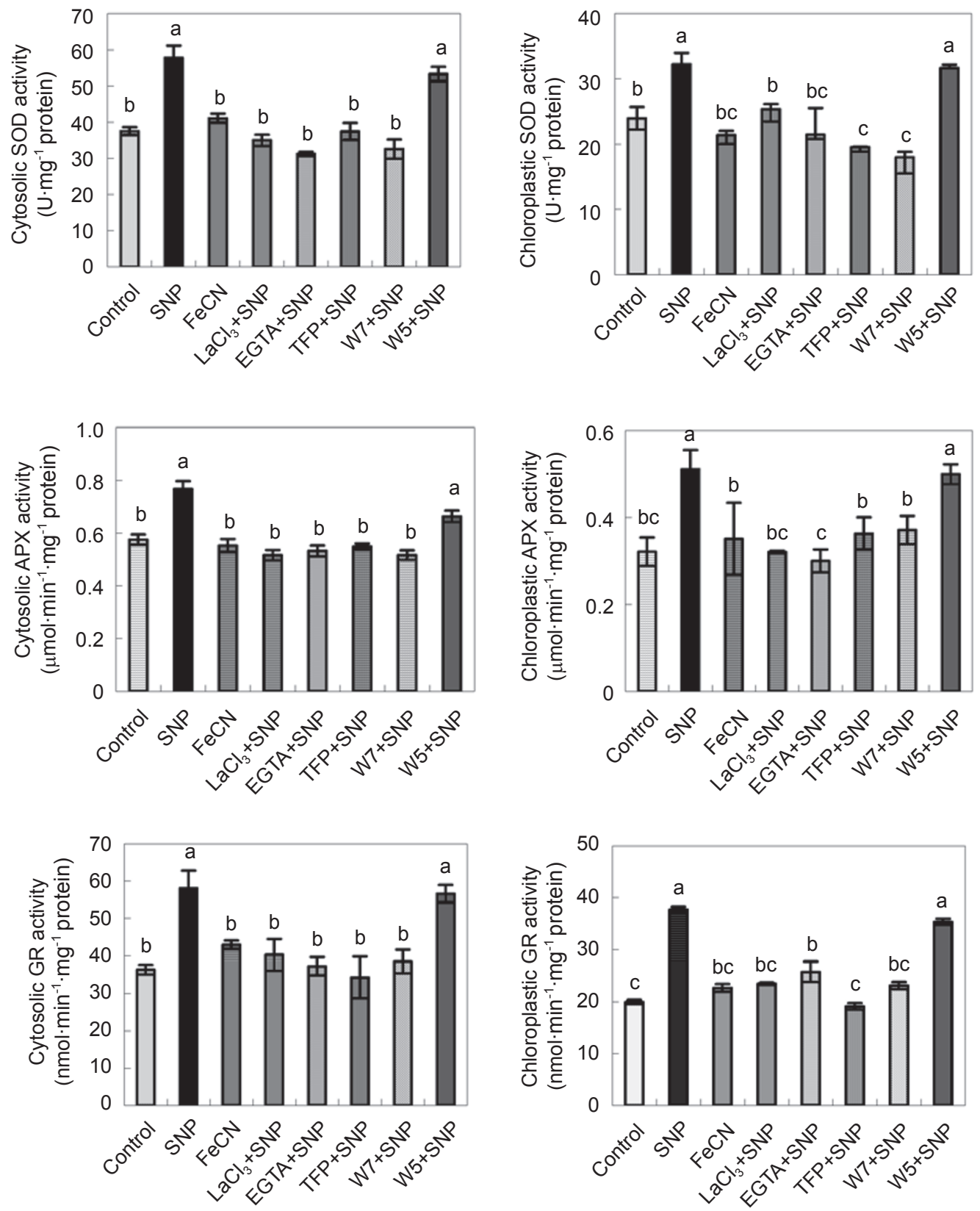
NOS. This enzyme catalyzes the oxygen- and NADPHdependent oxidation of L-arginine to L-citrulline and $\mathrm{NO}$ in a complex reaction requiring $\mathrm{FAD}, \mathrm{FMN}, \mathrm{BH}_{4}, \mathrm{Ca}^{2+}$, and $\mathrm{CaM}[12,14,17,18]$. In plants, pharmacological, biochemical and physicochemical, and immunological evidence indicates the presence of NOS-like activity similar, to a certain extent, to mammalian NOS [12, 14, 17, 18, 22-24], although no plant NOS similar to the mammalian one has been characterized [19-21]. It has been shown that NOS is localized in the cytoplasm, chloroplasts, mitochondria, peroxisomes, and nucleus in plant cells [14, 22, 24, 44]. The occurrence of NOS activity in pea leaf peroxisomes was demonstrated by biochemical methods and electron paramagnetic resonance (EPR) spectroscopy [22]. The enzyme was strictly dependent on L-arginine, NADPH, $\mathrm{BH}_{4}$, and $\mathrm{CaM}$, and required $\mathrm{Ca}^{2+}$. Previous studies showed that pretreatment with L-NAME, a well-known competitive inhibitor of mammalian NOS, reduced ABA-induced increase in the production of NO in pea guard cells [25] and maize mesophyll cells [11], suggesting that NOS is involved in ABA signaling. In this study, the activity of NOS in the cytosolic and microsomal fractions of maize leaves was determined. Our data showed that, under the control conditions, the activity of NOS in the microsomal fraction was higher than that in the cytosolic fraction. Treatment with $\mathrm{ABA}$ or $\mathrm{H}_{2} \mathrm{O}_{2}$ or $\mathrm{Ca}^{2+}$ induced increase in the activity of NOS in the cytosolic and microsomal fractions, and the increase was blocked by the pretreatments with the $\mathrm{Ca}^{2+}$ chelator EGTA, the $\mathrm{Ca}^{2+}$ channel blockers $\mathrm{LaCl}_{3}$ and verapamil, and the CaM antagonists TFP and W7 (Figures 2 and 3). Furthermore, pretreatments with the NOS inhibitors L-NAME and PBITU inhibited the activity of NOS induced by exogenous $\mathrm{Ca}^{2+}$ (Figure 2B), and also blocked the production of NO (Figure 1C). Our results clearly suggest that ABA- and $\mathrm{H}_{2} \mathrm{O}_{2}$-induced increase in the production of NO is mainly from NOS, which is $\mathrm{Ca}^{2+}$ and CaM-dependent. Our data also suggest that ABA and $\mathrm{H}_{2} \mathrm{O}_{2}$ could induce the activity of NOS, which is primarily located in the microsomal fraction, in different subcellular compartments. In previous studies, however, it was reported that NR was the main source of NO production in response to $\mathrm{ABA}$ and $\mathrm{H}_{2} \mathrm{O}_{2}$ in Arabidopsis guard cells $[38,45]$. The results described above suggest that there are different sources of $\mathrm{NO}$ in response to $\mathrm{ABA}$ and $\mathrm{H}_{2} \mathrm{O}_{2}$ in guard cells and mesophyll cells. However, we do not exclude that NR could also participate in the ABA- and $\mathrm{H}_{2} \mathrm{O}_{2}$-induced $\mathrm{NO}$ production in the mesophyll cells of maize leaves.

NO has also been shown to induce an increase in the concentration of $\left[\mathrm{Ca}^{2+}\right]_{\mathrm{i}}$ in plant cells. NO may mobilize $\mathrm{Ca}^{2+}$ from internal stores through the activation of ryanodine receptor (RYR)-like channels [15, 17, 40, 41, 46-48] and plasma membrane $\mathrm{Ca}^{2+}$-permeable channels $[40,41$, 47]. In the present study, our data showed that NO induced not only an increase in $\left[\mathrm{Ca}^{2+}\right]_{\mathrm{i}}$ in the protoplasts of maize leaves, which was sensitive to the plasma membrane $\mathrm{Ca}^{2+}$ channel blocker $\mathrm{LaCl}_{3}$ (Figure 4A), but also increases in the expression of $\mathrm{CaM1}$ (Figure 5A) and the content of $\mathrm{CaM}$ in leaves of maize plants (Figure 5B). Furthermore, ABAinduced $\mathrm{NO}$ production is also involved in the regulation of $\left[\mathrm{Ca}^{2+}\right]_{\mathrm{i}}$ and $\mathrm{CaM}$ because pretreatments with the NO scavenger c-PTIO and the NOS inhibitor L-NAME substantially reduced the $\mathrm{ABA}$-induced increases in the concentration of $\left[\mathrm{Ca}^{2+}\right]_{\mathrm{i}}$ (Figure 4B) and the expression of CaM1 (Figure 5A) and the content of $\mathrm{CaM}$ (Figure 5B) after the peak values. However, pretreatments with c-PTIO and L-NAME had very little effect on the ABA-induced increases in $\left[\mathrm{Ca}^{2+}\right]_{\mathrm{i}}$ and $C a M 1$ and $\mathrm{CaM}$ before the peak values, suggesting that $\mathrm{NO}$ is not required for the initial increases in $\left[\mathrm{Ca}^{2+}\right]_{\mathrm{i}}$ and $\mathrm{CaM}$ induced by ABA. Taken together, our results suggest that $\mathrm{Ca}^{2+}-\mathrm{CaM}$ functions both upstream and downstream of $\mathrm{NO}$ production in $\mathrm{ABA}$ and $\mathrm{H}_{2} \mathrm{O}_{2}$ signaling.

In a recent study, our data suggest that ABA-induced $\mathrm{H}_{2} \mathrm{O}_{2}$ production mediates $\mathrm{NO}$ generation, which in turn activates a MAPK and results in the up-regulation in expression and activities of antioxidant enzymes in ABA signaling in leaves of maize plants [11]. Moreover, $\mathrm{Ca}^{2+}-\mathrm{CaM}$ has also been shown to be involved in ABA-induced antioxidant defense [9]. However, whether $\mathrm{Ca}^{2+}-\mathrm{CaM}$ is also involved in the NO-induced antioxidant defense is not yet clear. In this study, we provide pharmacological evidence for the involvement of $\mathrm{Ca}^{2+}$-CaM in the NO-induced antioxidant defense. Our data showed that pretreatments with the $\mathrm{Ca}^{2+}$ chelator EGTA, the $\mathrm{Ca}^{2+}$ channel blocker $\mathrm{LaCl}_{3}$, and the CaM antagonists TFP and W7 substantially arrested the NO donor SNP-induced increases in the expression of the antioxidant genes SOD4, $C A P X$, and GR1 (Figure 6A) and

Figure 6 Effects of pretreatments with $\mathrm{Ca}^{2+}$ inhibitors and $\mathrm{CaM}$ antagonists on SNP-induced increases in the expression and activities of chloroplastic and cytosolic antioxidant enzymes in leaves of maize plants. (A) Transcript levels of the antioxidant genes SOD4, CAPX, and GR1 analyzed by RT-PCR. (B) The activities of the chloroplastic and cytosolic antioxidant enzymes SOD, APX, and GR. The detached plants were pretreated with distilled water, $10 \mathrm{mM} \mathrm{EGTA,} 5 \mathrm{mM} \mathrm{LaCl}_{3}, 100 \mu \mathrm{M}$ verapamil, $300 \mu \mathrm{M}$ TFP, $200 \mu \mathrm{M} \mathrm{W7}$, and $200 \mu \mathrm{M}$ W5 for $2 \mathrm{~h}$, respectively, and then exposed to $100 \mu \mathrm{M}$ SNP or $100 \mu \mathrm{M}$ Fe(III)CN treatment for $8 \mathrm{~h}(\mathrm{~A})$ or $12 \mathrm{~h}(\mathrm{~B})$. Detached plants treated with distilled water under the same conditions served as controls. In (A), experiments were repeated at least three times with similar results. In (B), the values are means \pm SE of three different experiments. Means denoted by the same letter did not significantly differ at $P<0.05$ according to Duncan's multiple range test. 
the activities of chloroplastic and cytosolic SOD, APX, and GR (Figure 6B), but pretreatment with W5 did not affect the SNP-induced increases in the expression and activities of these antioxidant enzymes. These results clearly suggest that $\mathrm{Ca}^{2+} / \mathrm{CaM}$ is required for NO-induced antioxidant defense in leaves of maize plants. It seems that there are at least two pathways in NO-induced antioxidant defense: one is NO-MAPK-antioxidant; another is NO- $\mathrm{Ca}^{2+} / \mathrm{CaM}$ antioxidant. However, $\mathrm{Ca}^{2+} / \mathrm{CaM}$ seems unlikely to directly regulate the activities of antioxidant enzymes in ABA signaling [9]. $\mathrm{A} \mathrm{Ca}^{2+}-\mathrm{CaM}$ kinase pathway associated with NO sensing may be involved in the regulation of ROSscavenging systems. To date, however, no information is available for the $\mathrm{Ca}^{2+}$-CaM kinase in plant cells.

\section{Materials and Methods}

\section{Plant material and treatments}

Seeds of maize (Zea mays L., cv. Nongda108; from Nanjing Agricultural University, China) were sown in trays of sand in a light chamber at a temperature of $22-28^{\circ} \mathrm{C}$, with a photosynthetic active radiation (PAR) of $200 \mu \mathrm{mol} \mathrm{m}^{-2} \mathrm{~s}^{-1}$ and a photoperiod of $14 / 10 \mathrm{~h}$ (day/ night), and watered daily. When the second leaf was fully expanded, the plants were collected and used for all investigations.

The plants were excised at the base of the stem and placed in the distilled water for $1 \mathrm{~h}$ to eliminate the wound stress. After the treatment, the cut ends of the stems were placed in beakers wrapped with aluminum foil containing $100 \mu \mathrm{M} \mathrm{ABA}, 10 \mathrm{mM} \mathrm{H}_{2} \mathrm{O}_{2}, 100$ $\mu \mathrm{M}$ sodium nitroprusside (SNP), and $10 \mathrm{mM} \mathrm{CaCl}_{2}$ solutions for various times at $25^{\circ} \mathrm{C}$ with a continuous light intensity of $200 \mu \mathrm{mol}$ $\mathrm{m}^{-2} \mathrm{~s}^{-1}$. In order to study the effects of inhibitors and scavengers, the detached plants were pretreated with $10 \mathrm{mM} \mathrm{EGTA,} 5 \mathrm{mM} \mathrm{LaCl}_{3}$, $100 \mu \mathrm{M}$ verapamil, $300 \mu \mathrm{M}$ TFP, $300 \mu \mathrm{M}$ W7 and $300 \mu \mathrm{M} \mathrm{N}-(6-$ aminohexyl)-1-naphthalene sulfonamide hydrochloride (W5) for 2 $\mathrm{h}$, respectively, and then exposed to $100 \mu \mathrm{M} \mathrm{ABA}$ or $10 \mathrm{mM} \mathrm{H}_{2} \mathrm{O}_{2}$ or $100 \mu \mathrm{M} \mathrm{SNP}$ or $10 \mathrm{mM} \mathrm{CaCl}_{2}$ treatment for various times up to $12 \mathrm{~h}$ under the same conditions as described above. Detached plants were treated with distilled water under the same conditions for the whole period and served as controls. After treatments of detached maize plants, the second leaves were sampled and immediately frozen under liquid $\mathrm{N}_{2}$.

\section{NO detection by CLSM}

NO measurement was performed with the specific NO dye DAF2DA, using the method as described [22] with slight modifications. Leaf segments of approximately $0.5 \mathrm{~cm}^{2}$ were incubated in loading buffer $\left(0.1 \mathrm{mM} \mathrm{CaCl}_{2}, 10 \mathrm{mM} \mathrm{KCl}, 10 \mathrm{mM}\right.$ MES-Tris, pH 5.6) and DAF-2DA at a final concentration of $10 \mu \mathrm{M}$ for $30 \mathrm{~min}$ in the dark at $25^{\circ} \mathrm{C}$, followed by washing twice in the same loading buffer for 15 min each. All images were visualized using CLSM (excitation $495 \mathrm{~nm}$, emission $515 \mathrm{~nm}$ ). Images acquired were analyzed using Leica IMAGE software. All experiments were repeated three times with similar results. Data are presented as average fluorescence intensity.

\section{NOS activity assay}

Crude enzyme extracts were prepared as described by Ninnemann and Maier [26], with some modifications. The frozen leaf tissues were homogenized in $5 \mathrm{~mL}$ of homogenization buffer $(50 \mathrm{mM}$ triethanolamine hydrochloride, $\mathrm{pH} 7.5$, containing 0.5 mM EDTA, 1 $\mathrm{mM}$ leupeptin, $1 \mathrm{mM}$ pepstatin, $7 \mathrm{mM} \mathrm{GSH}, 0.2 \mathrm{mM}$ PMSF). After centrifuging at $9000 \times g$ for $30 \mathrm{~min}\left(4^{\circ} \mathrm{C}\right)$, the supernatant was collected and recentrifuged at $100000 \times g$ for $1 \mathrm{~h}\left(4^{\circ} \mathrm{C}\right)$. The supernatant was used as cytosolic fraction. The pellet was resuspended in $1 \mathrm{~mL}$ of homogenization buffer and used as microsomal fraction. NOS activity was analyzed by hemoglobin assay as previously described $[27,28]$. Protein content was determined according to the method of Bradford [29] with BSA as standard.

\section{Preparation of protoplasts}

Maize mesophyll protoplasts were isolated using the method described by Shang et al. [30]. The cell wall was digested in enzyme solution, which contained $1.5 \%$ cellulose R10 (Yakult Honsha, Tokyo, Japan) and 0.4\% macerozyme R10 (Yakult Honsha, Tokyo, Japan). The isolated protoplasts were washed twice with washing and incubation solution comprising $0.5 \mathrm{M}$ mannitol, $4 \mathrm{mM}$ MES, $\mathrm{pH}$ 5.7, and $20 \mathrm{mM} \mathrm{KCl}$.

\section{Measurement of $\left[\mathrm{Ca}^{2+}\right]_{i}$}

For measurement of $\left[\mathrm{Ca}^{2+}\right]_{i}$, the maize mesophyll protoplasts were used to load the $\mathrm{Ca}^{2+}$-sensitive fluorescent dye Fluo-3/AM ester (Molecular Probes, Eugene, OR, USA) and make the CLSM observations according to the method described by Zhang et al. [31]. Fluo-3/AM was added from a stock solution of $1 \mathrm{mM}$ Fluo-3/AM in DMSO, after incubation at $25^{\circ} \mathrm{C}$ for $1 \mathrm{~h}$ in the dark. The incubation solution contained $20 \mu \mathrm{M}$ Fluo-3/AM ester, $0.5 \mathrm{M}$ mannitol, $4 \mathrm{mM}$ MES (pH 5.7), and $20 \mathrm{mM} \mathrm{KCl}$. Fluorescent probes were excited with a $488 \mathrm{~nm}$ laser, and emission fluorescent was filtered by a 515 $\mathrm{nm}$ filter to eliminate the autofluorescence of chlorophyll. Pictures were taken by scanning three times each $30 \mathrm{~s}$, and then the fluorescence intensities of these pictures were measured by fluorescence microscopy after establishing a stable baseline.

\section{Determination of CaM content}

For isolation of CaM, the maize leaves were ground in liquid $\mathrm{N}_{2}$, and then homogenized in buffer solution [50 mM Tris- $\mathrm{HCl}(\mathrm{pH} 8.0)$, $1 \mathrm{mM}$ EGTA, $0.5 \mathrm{mM}$ PMSF, $20 \mathrm{mM} \mathrm{NaHSO}_{4}$, and $0.15 \mathrm{M} \mathrm{NaCl}$ ] at $1: 1$ weight/volume $(\mathrm{w} / \mathrm{v})$. The homogenates were disintegrated by sonication for a total of $2 \mathrm{~min}$, treated in a water bath at $90-95^{\circ} \mathrm{C}$ for $3 \mathrm{~min}$ and then cooled, and then centrifuged at $10000 \times \mathrm{g}$ for $30 \mathrm{~min}$. The supernatants were used for measurement of protein content and $\mathrm{CaM}$ concentration. Protein content was determined according to the method of Bradford [29] with BSA as standard. CaM concentration was determined by enzyme-linked immunosorbent assay (ELISA) according to Sun et al. [32].

\section{Isolation of chloroplasts}

Chloroplasts were isolated from leaves using the method as described by Munné-Bosch and Alegre [33]. Briefly, after grinding $5 \mathrm{~g}$ leaves in isolation buffer [0.33 M sorbitol, 2 mM EDTA, 50 $\mathrm{mM}$ Hepes-KOH (pH 7.5), 0.1\% (w/v) BSA, $1 \mathrm{mM} \mathrm{MgCl}_{2}, 1 \mathrm{mM}$ $\left.\mathrm{MnCl}_{2}, 1 \mathrm{mM} \mathrm{DTT}\right]$, the homogenate was filtered through four layers of cheesecloth and centrifuged at $2{ }^{\circ} \mathrm{C}$ and $200 \times g$ for $1 \mathrm{~min}$. The pellet was resuspended in isolation buffer and then centrifuged at $2{ }^{\circ} \mathrm{C}$ and $2500 \times g$ for $5 \mathrm{~min}$. Chloroplasts were purified by resuspending the pellets in isolation buffer, laying on $12.5 \mathrm{~mL}$ of $25 \%$ 
(v/v) of Percoll (in isolation buffer), and centrifuging at $2{ }^{\circ} \mathrm{C}$ and $15800 \times g$ for $20 \mathrm{~min}$. The intact chloroplasts in lower layer were resuspended in isolation buffer without BSA and $\mathrm{MnCl}_{2}$, centrifuged at $2{ }^{\circ} \mathrm{C}$ and $2500 \times g$ for $5 \mathrm{~min}$. The chloroplast pellets were lysed in lyses buffer [50 mM phosphate buffer ( $\mathrm{pH} 7.8$ ), $0.1 \mathrm{mM}$ EDTA, $1 \mathrm{mM} \mathrm{MgCl}_{2}$ ] and used immediately for analyses. To detect APX activity, an independent organelle-isolation procedure was used (20 $\mathrm{mM}$ sodium ascorbate added to the extraction medium), and all other solutions also contained $2 \mathrm{mM}$ ascorbic acid to prevent the possible inactivation of APX.

\section{Preparation of cytosolic fraction}

Cytosolic fraction was isolated according to the method as described by Yang and Komatsu [34]. Leaf segments ( $0.5 \mathrm{~g})$ were homogenized in a mortar and pestle in $5 \mathrm{~mL}$ homogenization buffer containing $50 \mathrm{mM}$ phosphate buffer ( $\mathrm{pH} 7.5), 0.25 \mathrm{M}$ sucrose, 10 mM EGTA, $1 \mathrm{mM}$ DTT, and $1 \mathrm{mM}$ PMSF. The homogenates were centrifuged at $10000 \times g$ for $10 \mathrm{~min}$. The supernatants were centrifuged at $100000 \times g$ for $1 \mathrm{~h}$, and the cytosolic fraction was obtained by collecting the supernatant.

\section{Isolation of total RNA and RT-PCR}

Total RNA was isolated from leaves by using RNeasy mini kit (Qiagen) according to the instruction supplied by the manufacturer. Approximately $3 \mu \mathrm{g}$ of total RNA was reverse transcribed using oligo(dT) primer and SuperScript ${ }^{\mathrm{TM}}$ Reverse Transcriptase (Invitrogen). cDNA was amplified by PCR using the following primers: SOD4, forward TGC TCG CCT ACA AAT CCA and reverse TAG CGT TCT CAA ATG CTT AA; $c A P X$, forward TCG GCA CCA TGA AGA ACC C and reverse TCC TCG TCC GCT GCG TAT T; GR1, forward GAA GGT CGT GGA AAG ATA and reverse TTG GCA ACG AAG ACA TCA; CaM1, forward AAG CAT TCA GCC TCT TCG and reverse CAT CAT AAC CTT GAC AAA CTC C; $\beta$ actin, forward AAA TGA CGC AGA TTA TGT TTG A and reverse GCT CGT AGT GAG GGA GTA CC. To standardize the results, the relative abundance of $\beta$-actin was also determined and used as the internal standard.

The cycle number of the PCR reactions was adjusted for each gene to obtain barely visible bands in agarose gels. Aliquots of the PCR reactions were loaded on agarose gels and stained with ethidium bromide.

\section{Enzyme assays}

The activities of antioxidant enzymes were determined as previously described [35]. Total SOD activity was assayed by monitoring the inhibition of photochemical reduction of nitro blue tetrazolium. One unit of SOD activity was defined as the amount of enzyme that was required to cause $50 \%$ inhibition of the reduction of nitro blue tetrazolium as monitored at $560 \mathrm{~nm}$. APX activity was measured by monitoring the decrease in absorbance at $290 \mathrm{~nm}$ as ascorbate was oxidized. GR activity was measured by following the change in absorbance at $340 \mathrm{~nm}$ as oxidized glutathione (GSSG)-dependent oxidation of NADPH.

\section{Acknowledgments}

This work was supported by the Major State Basic Research Program of China (grant no. 2003CB114302 to M Jiang), the National Natural Science Foundation of China (grant no. 30571122 to M Jiang), and the Youth Scientific and Technological Innovation talent Project of Jiangsu Province (grant no. BK2007575 to A Zhang).

\section{References}

1 Finkelstein RR, Gampala SSL, Rock CD. Abscisic acid signaling in seeds and seedlings. Plant Cell 2002; 14:515-545.

2 Zhu JK. Salt and drought stress signal transduction in plants. Annu Rev Plant Biol 2002; 53:247-273.

3 Jiang $M$, Zhang J. Involvement of plasma membrane NADPH oxidase in abscisic acid- and water stress-induced antioxidant defense in leaves of maize seedlings. Planta 2002a; 215:10221030 .

4 Jiang M, Zhang J. Water stress-induced abscisic acid accumulation triggers the increased generation of reactive oxygen species and up-regulates the activities of antioxidant enzymes in maize leaves. J Exp Bot 2002b; 53:2401-2410.

5 Jiang M, Zhang J. Role of abscisic acid in water stress-induced antioxidant defense in leaves of maize seedlings. Free Radic Res 2002c; 36:1001-1015.

6 Jiang M, Zhang J. Abscisic acid and antioxidant defense in plant cells. Acta Bot Sin 2004; 46:1-9.

7 Jiang M, Zhang J. Cross-talk between calcium and reactive oxygen species originated from NADPH oxidase in abscisic acid-induced antioxidant defense in leaves of maize seedlings. Plant Cell Environ 2003; 26:929-939.

$8 \mathrm{Hu}$ X, Jiang M, Zhang A, Lu J. Abscisic acid-induced apoplastic $\mathrm{H}_{2} \mathrm{O}_{2}$ accumulation up-regulates the activities of chloroplastic and cytosolic antioxidant enzymes in maize leaves. Planta 2005; 223:57-68.

$9 \mathrm{Hu}$ X, Jiang M, Zhang J, Zhang A, Lin F, Tan M. Calcium/ calmodulin is required for abscisic acid-induced antioxidant defense and functions both upstream and downstream of $\mathrm{H}_{2} \mathrm{O}_{2}$ production in leaves of maize plants. New Phytol 2007; 173:2738.

10 Zhang A, Jiang M, Zhang J, Tan M, Hu X. Mitogen-activated protein kinase is involved in abscisic acid-induced antioxidant defense and acts downstream of reactive oxygen species production in leaves of maize plants. Plant Physiol 2006; 141:475-487.

11 Zhang A, Jiang M, Zhang J, et al. Nitric oxide induced by hydrogen peroxide mediates abscisic acid-induced activation of mitogen-activated protein kinase cascade involved in antioxidant defense in maize leaves. New Phytol 2007; 175:36-50.

12 Neill SJ, Desikan R, Hancock JT. Nitric oxide signaling in plants. New Phytol 2003; 159:11-35.

13 Desikan R, Cheung M-K, Bright J, Henson D, Hancock JT, Neill SJ. ABA, hydrogen peroxide and nitric oxide signaling in stomatal guard cells. J Exp Bot 2004; 55:205-212.

14 del Río LA, Corpas FJ, Barroso JB. Nitric oxide and nitric oxide synthase activity in plants. Phytochemistry 2004; 65:783-792.

15 Wendehenne D, Durner J, Klessig DF. Nitric oxide: a new player in plant signalling and defence responses. Curr Opin Plant Biol 2004; 7:449-455.

16 Delledonne M. NO news is good news for plants. Curr Opin Plant Biol 2005; 8:390-396.

17 Lamotte O, Courtois C, Barnavon L, Pugin A, Wendehenne D. Nitric oxide in plants: the biosynthesis and cell signaling properties of a fascinating molecule. Planta 2005; 221:1-4. 
18 Crawford NM. Mechanism for nitric oxide synthesis in plants. $J$ Exp Bot 2006; 57:471-478.

19 Crawford NM, Galli M, Tischner R, et al. Plant nitric oxide synthase: back to square one. Trends Plant Sci 2006; 11:526-527.

20 Zemojtel T, Fröhlich A, Palmieri MC, et al. Plant nitric oxide synthase: a never-ending story. Trends Plant Sci 2006; 11:524525 .

21 Neill SJ. Interactions between abscisic acid, hydrogen peroxide and nitric oxide mediate survival response during water stress. New Phytol 2007; 175:4-6.

22 Corpas FJ, Barroso JB, Carreras A, et al. Cellular and subcellular localization of endogenous nitric oxide in young and senescent pea plants. Plant Physiol 2004; 136:2722-2733.

23 Corpas FJ, Barroso JB, Carreras A, et al. Constitutive argininedependent nitric oxide synthase activity in different organs of pea seedlings during plant development. Planta 2006; 224:246254.

24 Liu X, Wang YQ, Jia WS, Lou CH, Zhang SQ. Localization of NOS-like protein in guard cells of Vicia faba L. and its possible function. Chin Sci Bull 2007; 52:84-90.

25 Neill SJ, Desikan R, Clarke A, Hancock JT. Nitric oxide is a novel component of abscisic acid signalling in stomatal guard cells. Plant Physiol 2002; 128:13-16.

26 Ninnemann H, Maier J. Indications for the occurrence of nitric oxide synthases in fungi and plants and the involvement in photoconidiation of Neurospora crassa. Photochem Photobiol 1996; 64:393-398.

27 Hevel JM, Marletta MA. Nitric oxide synthase assays. Methods Enzymol 1994; 233:250-258.

28 Murphy ME, Noack E. Nitric oxide assay using haemoglobin method. Methods Enzymol 1994; 233:241-250.

29 Bradford MM. A rapid and sensitive method for the quantitation of microgram quantities of protein utilizing the principle of protein-dye binding. Anal Biochem 1976; 72:248-254.

30 Shang ZL, Ma LG, Zhang HL, et al. $\mathrm{Ca}^{2+}$ influx into lily pollen grains through a hyperpolarization-activated $\mathrm{Ca}^{2+}$-permeable channel which can be regulated by extracellular CaM. Plant Cell Physiol 2005; 46:598-608.

31 Zhang WH, Rengel Z, Kuo J. Determination of intracellular $\mathrm{Ca}^{2+}$ in cells of intact wheat roots: loading of acetoxymethyl ester of Fluo-3 under low temperature. Plant J 1998; 15:147-151.

32 Sun DY, Bian YQ, Zhao BH, Zhao LY, Yu XM, Duan SJ. The effects of extracellular calmodulin on cell wall regeneration of protoplasts and cell division. Plant Cell Physiol 1995; 36:133138.

33 Munné-Bosch S, Alegre L. Drought-induced changes in the redox state of a-tocopherol, ascorbate, and the diterpene carnosic acid in chloroplasts of Labiatae species differing in carnosic acid contents. Plant Physiol 2003; 131:1816-1825.

34 Yang G, Komatsu S. Involvement of calcium-dependent protein kinase in rice (Oryza sativa L.) lamina inclination caused by brassinolide. Plant Cell Physiol 2000; 141:1243-1250.

35 Jiang M, Zhang J. Effect of abscisic acid on active oxygen species, antioxidative defence system and oxidative damage in leaves of maize seedlings. Plant Cell Physiol 2001; 42:1265-1273.

36 Bethke PC, Libourel IGL, Reinöhl V, Jones RL. Sodium nitroprusside, cyanide, nitrite, and nitrate break Arabidopsis seed dormancy in a nitric oxide-dependent manner. Planta 2006; 223:805-812.

37 Breton C, Chaboud A, Matthys-Rochon E, et al. PCR-generated cDNA library of transition-stage maize embryos: cloning and expression of calmodulin genes during early embryogenesis. Plant Mol Biol 1995; 27:105-113.

38 Bright J, Desikan R, Hancock JT, Weir IS, Neill SJ. ABA-induced NO generation and stomatal closure in Arabidopsis are dependent on $\mathrm{H}_{2} \mathrm{O}_{2}$ synthesis. Plant J 2006; 45:113-122.

39 Lum HK, Butt YK, Lo SC. Hydrogen peroxide induces a rapid production of nitric oxide in mung bean (Phaseolus aureus). Nitric Oxide 2002; 6:205-213.

40 Lamotte O, Gould K, Lecourieux D, et al. Analysis of nitric oxide signaling functions in tobacco cells challenged by the elicitor cryptogein. Plant Physiol 2004; 135:516-529.

41 Vandelle E, Poinssot B, Wendehenne D, Bentejac M, Pugin A. Integrated signaling network involving calcium, nitric oxide, and active oxygen species but not mitogen-activated protein kinases in BcPG1-elicited grapevine defenses. Mol Plant Microbe Interact 2006; 19:429-440.

42 Larkindale J, Knight MR. Protection against heat stress-induced oxidative damage in Arabidopsis involves calcium, abscisic acid, ethylene, and salicylic acid. Plant Physiol 2002; 128:682-695.

43 Liu HT, Li B, Shang ZL, et al. Calmodulin is involved in heat shock signal transduction in wheat. Plant Physiol 2003; 132:1186-1195.

44 Guo FQ, Crawford NM. Arabidopsis nitric oxide synthase 1 is targeted to mitochondria and protects against oxidative damage and dark-induced senescence. Plant Cell 2005; 17:3436-3450.

45 Desikan R, Griffiths R, Hancock JT, Neill SJ. A new role for an old enzyme: nitrate reductase-mediated nitric oxide generation is required for abscisic acid-induced stomatal closure in Arabidopsis thaliana. Proc Natl Acad Sci USA 2002; 99:16314-16318.

46 Garcia-Mata C, Gay R, Sokolovski S, Hills A, Lamattina L, Blatt MR. Nitric oxide regulates $\mathrm{K}^{+}$and $\mathrm{Cl}^{-}$channels in guard cells through a subset of abscisic acid-evoked signaling pathways. Proc Natl Acad Sci USA 2003; 100:11116-11121.

47 Lamotte O, Courtois C, Dobrowolska G, Besson A, Pugin A, Wendehenne D. Mechanisms of nitric-oxide-induced increase of free cytosolic $\mathrm{Ca}^{2+}$ concentration in Nicotiana plumbaginifolia cells. Free Radic Biol Med 2006; 40:1369-1376.

48 Lecourieux D, Ranjeva R, Pugin A. Calcium in plant defencesignaling pathways. New Phytol 2006; 171:249-269. 